\title{
Substrate Acidification by Geranium: Light Effects and Phosphorus Uptake
}

\author{
Matthew D. Taylor ${ }^{1}$ and Paul V. Nelson ${ }^{2,4}$ \\ Department of Horticultural Science, North Carolina State University, Raleigh, NC 27695-7609 \\ Jonathan M. Frantz ${ }^{3}$ \\ U.S. Department of Agriculture-Agricultural Research Service Application Technology Research \\ Unit, Toledo, $\mathrm{OH} 43606$
}

\begin{abstract}
AdDitional Index words. Pelargonium $\times$ hortorum, $\mathrm{pH}, P P F$
Abstract. Sudden pH decline (SPD) describes the situation where crops growing at an appropriate pH rapidly (within 1-2 weeks) cause the substrate pH to shift downward one to two units. 'Designer Dark Red' geraniums (Pelargonium $\times$ hortorum Bailey) were grown in three experiments to assess possible effects of light on SPD and phosphorous (P) uptake. The first experiment tested the effect of four light intensities $\left(105,210,575\right.$, and $\left.1020 \pm 25 \mu \mathrm{mol} \cdot \mathrm{m}^{-2} \cdot \mathrm{s}^{-1}\right) \mathrm{on}^{2}$ substrate acidification. At 63 days, substrate pH declined from 6.0 to 4.8 as light intensity increased. Tissue $P$ of plants grown at the highest two light levels was extremely low $(0.10 \%-0.14 \%$ of dry weight $)$. $P$ stress has been reported to cause acidification. Because plants in the two lowest light treatments had adequate $P$, it was not possible to determine if the drop in substrate $\mathrm{pH}$ was a direct light effect or a combination of light and $\mathrm{P}$. The second experiment used a factorial combination of the three highest light levels from Expt. 1 and five preplant $P$ rates $(0,0.065,0.13,0.26$, or $0.52 \mathrm{~g} \cdot \mathrm{L}^{-1}$ substrate) to assess this question. When tissue $\mathrm{P}$ concentrations were deficient, $\mathrm{pH}$ decreased by 0.6 to $1.0 \mathrm{pH}$ units within 2 weeks and deficiency occurred more often with high light intensity. These data indicated that $P$ deficiency caused substrate acidification and indicated the possibility that $P$ uptake was suppressed by high light intensity. The third experiment was conducted in hydroponics to determine the direct effect of high light intensity on $P$ uptake. In this experiment, cumulative $P$ uptake per gram root and the rate of $P$ uptake per gram root per day both decreased $20 \%$ when light intensity increased from 500 to $1100 \mu \mathrm{mol} \cdot \mathrm{m}^{-2} \cdot \mathrm{s}^{-1}$. It is clear from this study that $P$ deficiency causes geraniums to acidify the substrate and that high light suppresses $P$ uptake.
\end{abstract}

Sudden $\mathrm{pH}$ decline (SPD) describes the situation where crops growing at an appropriate $\mathrm{pH}$ rapidly (within 1-2 weeks) cause the substrate $\mathrm{pH}$ to shift downward one to two units. Phosphorus (P) deficiency has been shown to cause plants to acidify substrate (Hinsinger, 2001; Schjorring, 1986). Taylor et al. (2008) reported that low tissue $\mathrm{P}$ and high temperature stress caused geraniums to lower substrate $\mathrm{pH}$. In addition to low $\mathrm{P}$ and high temperature, high light may also be associated with SPD. Micronutrient toxicity symptoms have been reported to occur in geranium shortly after periods of high light (White, 1993). Tomato (Solanum lycopersicum L.), boston fern (Nephrolepis exaltata L.), and guinea grass (Panicum maximum Jacq.) have been shown to increase $P$ uptake under higher light intensity (Anita et al., 2003; De Groot et al., 2001; Magalhaes and Wilcox, 1983; Nowak et al., 2002). Most light treatments used in these studies were below what would normally occur during spring geranium production. It is possible that light intensities provided ranged from suboptimal to adequate. If

Received for publication 7 Dec. 2007. Accepted for publication 2 Apr. 2008. Mention of a trademark, proprietary product, or vendor does not constitute a guarantee or warranty of the product by the U.S. Dept. of Agriculture and does not imply its approval to the exclusion of other products or vendors that also may be suitable.

The authors gratefully acknowledge the scientists and staff of the North Carolina State University Phytotron; Ball Floraplant, Will Healy, and Kristan McGuigan for providing guidance and plant material; and Nancy Mingus, Elizabeth Taylor, Douglas Sturtz, and Elisa Ruszkiewicz for technical assistance.

${ }^{1}$ Graduate research assistant

${ }^{2}$ Professor.

${ }^{3}$ Research Horticulturist.

${ }^{4}$ Corresponding author. E-mail: paul_nelson@ncsu.edu. higher light intensities were applied, a negative effect on $\mathrm{P}$ uptake could have occurred. The objective of this research was to assess the effect of high light intensity on substrate acidification and $\mathrm{P}$ uptake.

\section{Materials and Methods}

EXPT. 1. Rooted 'Designer Dark Red' (zonal) and 'Galleria Bright Violet' (ivy) geranium cuttings were fumigated for insects overnight with $0.5 \%$ Bifenthrin (Attain TR; Whitmire Micro-Gen Research Laboratories, St. Louis), planted the following day into $11-\mathrm{cm}$-diameter $\left(606 \mathrm{~cm}^{3}\right)$ azalea pots, and grown for $63 \mathrm{~d}$ at the North Carolina State University Phytotron. The substrate consisted of 3:1 (by volume) peat: perlite amended with $\mathrm{MgSO}_{4}$, Micromax micronutrient mix (The Scotts Co., Marysville, OH), triple-superphosphate $(19.7 \% \mathrm{P})$ at $0.59,0.89$, and $0.26 \mathrm{~g} \cdot \mathrm{L}^{-1}$ substrate, respectively, and flowable dolomitic limestone (Cleary Chemical Corporation, Dayton, NJ) at $8.3 \mathrm{~mL} \cdot \mathrm{L}^{-1}$ substrate. Treatments were arranged in a factorial design with four light treatments $(105$, 210,575 , and $1020 \pm 25 \mu \mathrm{mol} \cdot \mathrm{m}^{-2} \cdot \mathrm{s}^{-1}$ ) selected to range from sub- to superoptimal and two cultivars. There were three replications and two single plant pots per plot, resulting in a total of 48 plants. Plants in the three lowest light treatments were grown in growth chambers with $9 \mathrm{~m}^{2}$ of growing area and $2.13 \mathrm{~m}$ vertical clearance. Light was provided by cool white fluorescent and incandescent lamps separated from the growing area by a polycarbonate barrier. The 210 and $105 \mu \mathrm{mol} \cdot \mathrm{m}^{-2} \cdot \mathrm{s}^{-1}$ light treatments were achieved by using one and two layers of green shadecloth (army surplus mosquito netting), respectively. In the highest light treatment, plants were grown in chambers 
with $1.1 \mathrm{~m}^{2}$ of growing area and $1.2 \mathrm{~m}$ vertical clearance. Light was provided by incandescent lamps and an equal ratio of metal halide-to-high pressure sodium lamps separated from the growing area by a polycarbonate barrier. The standard longday photoperiod provided by the Phytotron was used. This light regime for all light treatments consisted of a 9-h photosynthetic light period, $6 \mathrm{~h}$ of darkness, a 3 -h low-light night interruption, and $6 \mathrm{~h}$ of darkness. The 3-h low-light night interruption was provided by incandescent lamps and supplied a photosynthetic photon flux $(P P F)$ of $25 \mu \mathrm{mol} \cdot \mathrm{m}^{-2} \cdot \mathrm{s}^{-1}$. The day/night temperature in all chambers was $22 / 18{ }^{\circ} \mathrm{C}$. Carbon dioxide concentrations were maintained between 300 and $400 \mu \mathrm{L} \cdot \mathrm{L}^{-1}$ by controlled injection of commercial grade gas. Plants were fertilized with each irrigation with a solution made from deionized water consisting of $1.4 \mathrm{~mm} \mathrm{NH} \mathrm{NNO}_{3}, 3.6 \mathrm{~mm}$ $\mathrm{Ca}\left(\mathrm{NO}_{3}\right)_{2}$, and $4 \mathrm{~mm} \mathrm{KNO}_{3}$ (N, $\mathrm{K}$, and $\mathrm{Ca}$ at 196,156 , and $144 \mathrm{mg} \cdot \mathrm{L}^{-1}$, respectively).

EXPT. 2. This experiment was similar to Expt. 1 except that it had one cultivar ('Designer Dark Red'), three light treatments $\left(210,575\right.$, and $\left.1020 \pm 25 \mu \mathrm{mol} \cdot \mathrm{m}^{-2} \cdot \mathrm{s}^{-1}\right)$, five $\mathrm{P}$ treatments $(0$, $0.065,0.13,0.26$, or $0.52 \mathrm{~g} \cdot \mathrm{L}^{-1}$ substrate), and two single plant pots per plot. There were three replications, giving a total of 90 plants. Lime in the substrate was $\mathrm{CaCO}_{3}$ powder (Fisher Scientific, Pittsburgh) supplied at $3.5 \mathrm{~g} \cdot \mathrm{L}^{-1}$ because the flowable dolomitic limestone caused substrate $\mathrm{pH}$ to rise for the first 5 weeks during Expt. 1 (Fig. 1).

EXPTS. 1 AND 2 MEASUREMENTS. Substrate $\mathrm{pH}$ was measured via the pour-through technique (Wright, 1986) every $7 \mathrm{~d}$ for the duration of both experiments, and immediately after each pourthrough, plants were fertilized. In Expt. 2, pour-through extracts taken at 14, 28, 42, and $56 \mathrm{~d}$ after transplanting (DAT) were also analyzed for P. At 63 DAT, four to six recently mature leaves in both experiments and the oldest leaves in Expt. 2 were removed from plants, rinsed with $0.1 \mathrm{~N}$ $\mathrm{HCl}$, and rinsed again with deionized water. Plant samples from all three experiments were dried in a forced-air oven at $60{ }^{\circ} \mathrm{C}$ for $48 \mathrm{~h}$, weighed, ground in a Wiley mill through a 25 -mesh screen (1-mm particle size), and the P content of both leaf samples and pour-through extracts were determined with inductively coupled plasma optical emission spectroscopy (IRIS-Intrepid II; Thermo Fisher Scientific, Waltham, MA). Pour-though P concentrations were not detectable (ND) below the lower limit of $11 \mu \mathrm{g} \cdot \mathrm{L}^{-1}$. All tissue concentrations are expressed on a dry weight basis. In Expt. 2, total shoot $\mathrm{P}$ was determined by multiplying the dry weight of the shoots by the average of the dry weight percentage of $\mathrm{P}$ of recently mature leaves and the oldest leaves. Experimental data were statistically analyzed as a complete block design with mean separation by Duncan's multiple range test at $P=0.05$ using SAS (version 9.1; SAS Institute, Cary, NC).

ExpT. 3. 'Designer Dark Red' geranium cuttings, partially rooted in Oasis ${ }^{\circledR}$ Wedge ${ }^{\circledR}$ growing foam (Smithers-Oasis North America, $\mathrm{OH}$ ), were fumigated overnight, as in Expts. 1 and 2 . The following day, they were placed in the same type of growth chambers used for the low- and medium-light treatments in Expts. 1 and 2. The temperature was $22{ }^{\circ} \mathrm{C}$ day $/ 18^{\circ} \mathrm{C}$ night. Plants were fertilized daily with the standard nutrient solution provided by the Phytotron. This solution contained N, $\mathrm{P}, \mathrm{K}, \mathrm{Ca}, \mathrm{Mg}, \mathrm{Fe}, \mathrm{S}, \mathrm{Mn}, \mathrm{B}, \mathrm{Zn}, \mathrm{Cu}, \mathrm{Mo}$, and $\mathrm{Na}$ at 106, 10, 111, $54,12,5,13,0.1,0.2,0.01,0.005,0.005$, and $11 \mathrm{mg} \cdot \mathrm{L}^{-1}$, respectively. After $12 \mathrm{~d}, 48$ rooted cuttings were transplanted into 12 opaque plastic buckets containing $4 \mathrm{~L}$ of nutrient

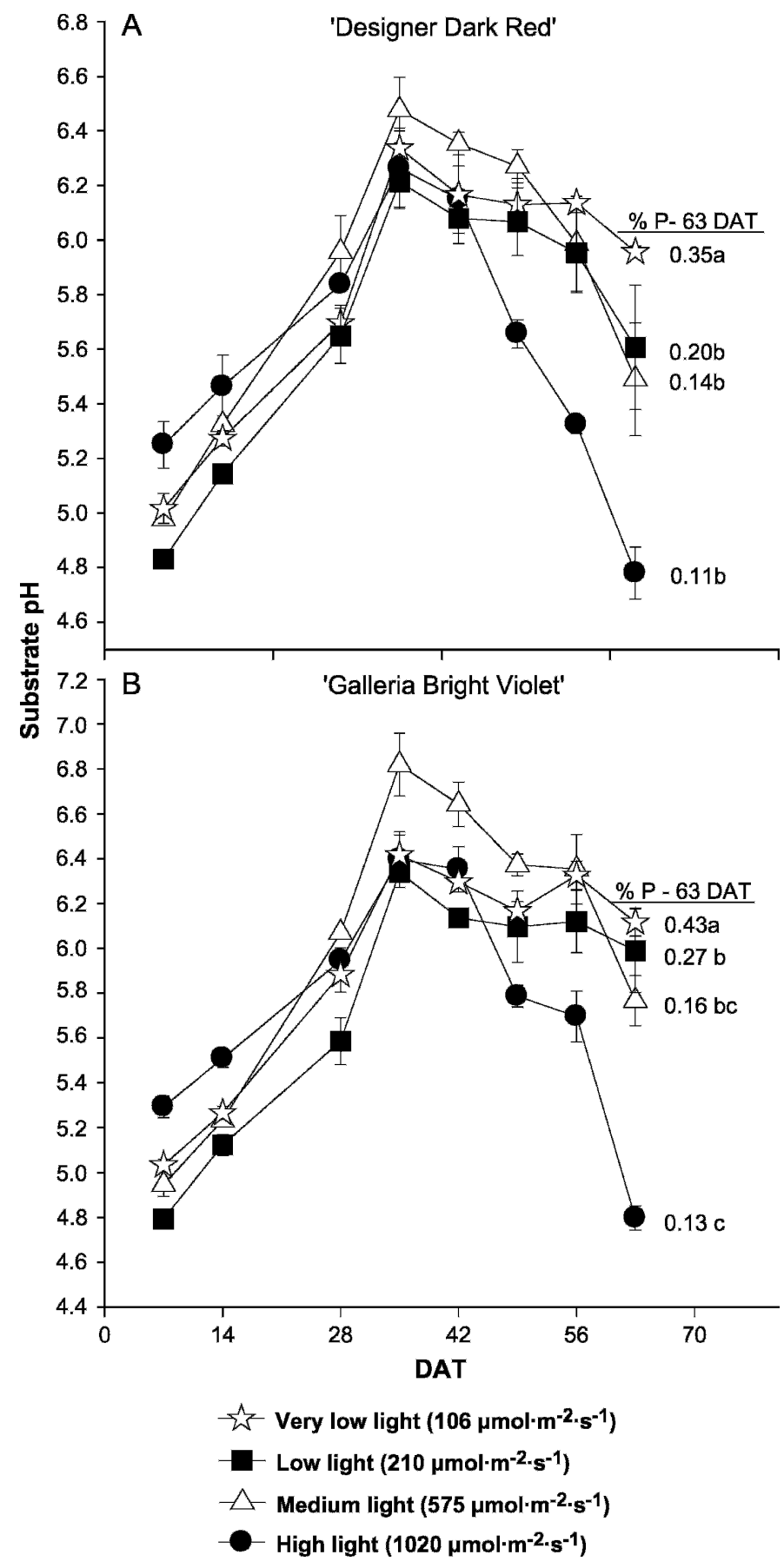

Fig. 1. Substrate $\mathrm{pH}$ of geraniums measured every $7 \mathrm{~d}$ after transplanting (DAT) for 'Designer Dark Red' (A) and 'Galleria Bright Violet' (B) geraniums at very low $\left(105 \mu \mathrm{mol} \cdot \mathrm{m}^{-2} \cdot \mathrm{s}^{-1}\right)$, low $\left(210 \mu \mathrm{mol} \cdot \mathrm{m}^{-2} \cdot \mathrm{s}^{-1}\right)$, medium $(575$ $\left.\mu \mathrm{mol} \cdot \mathrm{m}^{-2} \cdot \mathrm{s}^{-1}\right)$, and high $\left(1020 \mu \mathrm{mol} \cdot \mathrm{m}^{-2} \cdot \mathrm{s}^{-1}\right)$ light in Expt. 1. Error bars represent SE $(n=3)$. On the right side of each light curve is the tissue dry weight percentage of $P 63$ DAT. Mean separation by Duncan's multiple range test at $P \leq 0.05$.

solution. Buckets were covered with plastic lids with four evenly spaced 2.5 -cm-diameter holes to hold plants and were placed into two chambers that were the same type as the highlight chambers used in Expts. 1 and 2. The day/night temperature was $22^{\circ} \mathrm{C}$ day $/ 18^{\circ} \mathrm{C}$ night, and one of the chambers was shaded with standard window screen with a mesh size of $7.1 \times$ 6.3 per $\mathrm{cm}^{2}$, giving $\approx 50 \%$ light exclusion for the control light 
treatment. The hydroponic containers were aerated and filled with solutions consisting of $1.5 \mathrm{~mm} \mathrm{NH} \mathrm{NO}_{3}, 5 \mathrm{~mm} \mathrm{Ca}\left(\mathrm{NO}_{3}\right)_{2}$, $2 \mathrm{mM} \mathrm{KNO}_{3}, 1 \mathrm{~mm} \mathrm{KH} \mathrm{PO}_{4}, 1.5 \mathrm{~mm} \mathrm{KCl}, 2 \mathrm{mM} \mathrm{MgSO}_{4}, 69 \mu \mathrm{M}$ Fe from Fe-DTPA, $9.1 \mu \mathrm{M} \mathrm{MnSO} \cdot \mathrm{H}_{2} \mathrm{O}, 0.76 \mu \mathrm{M} \mathrm{ZnSO}_{4} \cdot 7 \mathrm{H}_{2} \mathrm{O}$, $46.3 \mu \mathrm{M} \mathrm{H}_{3} \mathrm{BO}_{3}, 1.57 \mu \mathrm{M} \mathrm{CuSO}_{4} \cdot 5 \mathrm{H}_{2} \mathrm{O}$, and $0.10 \mu \mathrm{M}$ $\mathrm{Na}_{2} \mathrm{MoO}_{4} \cdot 2 \mathrm{H}_{2} \mathrm{O}$. The volume of the containers was maintained by the addition of deionized water every 2 to $3 \mathrm{~d}$.

This experiment was a factorial design with two light treatments (500 and $1100 \pm 25 \mu \mathrm{mol} \cdot \mathrm{m}^{-2} \cdot \mathrm{s}^{-1}$ ), two sampling dates (11 and $15 \mathrm{DAT}$ ), and three replications with four plants per plot. On each sampling date, plants were removed and roots were rinsed with deionized water so that all the solution remaining on the roots was washed back into the bucket. Plants were then separated into roots and shoots. Roots were dipped in $1 \mathrm{mM} \mathrm{CaSO}_{4}$ for $30 \mathrm{~s}$ followed by deionized water to remove ions from the apoplast (Naegle et al., 2005), patted dry, and weighed. Shoots were weighed, rinsed with $0.1 \mathrm{~N} \mathrm{HCl}$, rinsed again with deionized water, and then both roots and shoots were dried and weighed again. All leaves with petioles were removed from the stems for tissue analysis as described previously. Roots were also analyzed. Solutions in buckets were brought back to volume with deionized water and were analyzed for $\mathrm{P}$ content to determine $\mathrm{P}$ uptake by roots. Phosphorus concentration of hydroponic solution was determined by the colorimetric method of Murphy and Riley (1962).

\section{Results and Discussion}

ExPT. 1. For all light treatments and both cultivars, $\mathrm{pH}$ increased from less than 5.3 to greater than 6.1 during the first $35 \mathrm{~d}$ (Fig. 1). This unforeseen increase in substrate $\mathrm{pH}$ could be a consequence of an unexpectedly slow dissolution of the preplant flowable dolomitic limestone. All interactions were significant for substrate $\mathrm{pH}$ and tissue percentage of P. Starting 49 DAT, substrate $\mathrm{pH}$ of plants grown at high light (1020 $\left.\mu \mathrm{mol} \cdot \mathrm{m}^{-2} \cdot \mathrm{s}^{-1}\right)$ were lower than plants from all other light treatments (Fig. 1). Substrate $\mathrm{pH}$ decreased to 4.78 for 'Designer Dark Red' and 4.80 for 'Galleria Bright Violet' by 63 DAT. At this point, substrate $\mathrm{pH}$ of 'Designer Dark Red' plants grown at very low light $\left(106 \mu \mathrm{mol} \cdot \mathrm{m}^{-2} \cdot \mathrm{s}^{-1}\right)$ was 5.96 and greater than plants at the low $\left(210 \mu \mathrm{mol} \cdot \mathrm{m}^{-2} \cdot \mathrm{s}^{-1}\right)$ and medium $\left(575 \mu \mathrm{mol} \cdot \mathrm{m}^{-2} \cdot \mathrm{s}^{-1}\right)$ light levels, which had statistically similar $\mathrm{pH}$ values of 5.61 and 5.49, respectively. 'Galleria Bright Violet' plants at the very low, low, and medium light levels had statistically similar substrate $\mathrm{pH}$ levels of 6.12, 5.99, and 5.77, respectively.

Krug et al. (2006) determined that the lower end of the acceptable range for tissue dry weight $\mathrm{P}$ concentration in recently mature leaves for mature zonal geraniums is $0.17 \%$ to $0.19 \%$. Although substrate $\mathrm{pH}$ decreased with increasing light, tissue $\mathrm{P}$ was deficient in both cultivars grown at medium and high light (Fig. 1). Acidification due to $\mathrm{P}$ deficiency is a widespread phenomenon among dicotyledonous species (Marschner, 1995). Phosphorus deficiency was also visually apparent in this experiment and was expressed as interveinal and marginal yellowing and reddening of the lower leaves.

It is unclear why the increasing light levels caused the observed drop in substrate $\mathrm{pH}$. In addition to high light intensity and $\mathrm{P}$ deficiency, larger root systems producing more acidity is possible because dry weights of shoots increased with increasing light intensity for both cultivars (Table 1). A fourth possibility could be the increased number of irrigations (Table
Table 1. Main effects of light and cultivar on dry weights of shoots of geranium plants $63 \mathrm{~d}$ after transplanting from Expt. 1 .

\begin{tabular}{lc}
\hline & Dry wt $(\mathrm{g})$ \\
\hline Light treatment & \\
Very low light $\left(105 \mu \mathrm{mol} \cdot \mathrm{m}^{-2} \cdot \mathrm{s}^{-1}\right)$ & $4.3 \mathrm{~d}^{\mathrm{z}}$ \\
Low light $\left(210 \mu \mathrm{mol} \cdot \mathrm{m}^{-2} \cdot \mathrm{s}^{-1}\right)$ & $10.6 \mathrm{c}$ \\
Medium light $\left(575 \mu \mathrm{mol} \cdot \mathrm{m}^{-2} \cdot \mathrm{s}^{-1}\right)$ & $20.8 \mathrm{~b}$ \\
High light $\left(1020 \mu \mathrm{mol} \cdot \mathrm{m}^{-2} \cdot \mathrm{s}^{-1}\right)$ & $27.2 \mathrm{a}$ \\
Cultivar & \\
Designer Dark Red & $17.8 \mathrm{a}$ \\
Galleria Bright Violet & $13.6 \mathrm{~b}$ \\
\hline
\end{tabular}

${ }^{\mathrm{z}}$ Mean separation by Duncan's multiple range test at $P \leq 0.05$.

Table 2. Number of irrigations applied to geranium plants in the very low, low, medium, and high light treatments in Expts. 1 and 2.

\begin{tabular}{lcc}
\hline & Expt. 1 & Expt. 2 \\
\cline { 2 - 3 } Light treatment & \multicolumn{2}{c}{ Irrigations (no.) } \\
\hline Very low light $\left(105 \mu \mathrm{mol} \cdot \mathrm{m}^{-2} \cdot \mathrm{s}^{-1}\right)$ & 20 & - \\
Low light $\left(210 \mu \mathrm{mol} \cdot \mathrm{m}^{-2} \cdot \mathrm{s}^{-1}\right)$ & 34 & 17 \\
Medium light $\left(575 \mu \mathrm{mol} \cdot \mathrm{m}^{-2} \cdot \mathrm{s}^{-1}\right)$ & 41 & 27 \\
High light $\left(1020 \mu \mathrm{mol} \cdot \mathrm{m}^{-2} \cdot \mathrm{s}^{-1}\right)$ & & 37
\end{tabular}

2). As the irrigation rate increases, lime may have been leached more quickly, causing a more rapid drop in substrate $\mathrm{pH}$.

ExPT. 2. All interactions were significant for substrate $\mathrm{pH}$. At 7 DAT, substrate $\mathrm{pH}$ decreased with each increase in $\mathrm{P}$ rate for all light treatments (Fig. 2). Triple superphosphate was the $\mathrm{P}$ source and is composed primarily of monocalcium-phosphate hydrate. A saturated solution of monocalcium-phosphatehydrate has a $\mathrm{pH}$ of 1.0 to 1.5 , indicating higher rates will cause lower initial substrate $\mathrm{pH}$ (Khasawneh et al., 1978). The effect of $\mathrm{P}$ rate on substrate $\mathrm{pH}$ diminished after 7 DAT and was gone by 35 DAT. At all light intensities, substrate $\mathrm{pH}$ of plants grown without $\mathrm{P}$ began to decrease immediately and $\mathrm{pH}$ largely continued to decline for the length of the study. Plants that did not receive $P$ had the lowest percentage of $P$ in all cases and would be expected to have the highest acidification rate due to the severity of the P deficiency. This effect did not occur and is most likely due to reduced plant growth (Table 3). Small, severely stunted plants would have less effect on rhizosphere acidification than larger plants with mild to moderate $\mathrm{P}$ deficiency. Plants grown with zero $\mathrm{P}$ were small in overall size, the younger leaves were small and dark green, and the older leaves were reddish, chlorotic, and necrotic, and eventually turned completely necrotic and senesced.

At 63 DAT under low light, substrate $\mathrm{pH}$ of plants grown with $0.065 \mathrm{~g} \cdot \mathrm{L}^{-1} \mathrm{P}$ was 5.30 and lower than the substrate $\mathrm{pH}$ of all other plants (Fig. 2). Plants grown at low light and the 0.065 $\mathrm{g} \cdot \mathrm{L}^{-1} \mathrm{P}$ rate had recently mature leaf percentage of $\mathrm{P}$ of 0.14 at 63 DAT, which is below the accepted lower limit $(0.17 \%$ $0.19 \%$ ) (Table 3). All other P treatments at low light, except zero $\mathrm{P}$, had recently mature leaf percentage of $\mathrm{P}$ above $0.19 \%$ and had the highest substrate $\mathrm{pH}$, suggesting low $\mathrm{pH}$ was due to $\mathrm{P}$ deficiency. At 63 DAT under medium light intensity, substrate $\mathrm{pH}$ of plants that received the highest or lowest $\mathrm{P}$ rate was greater than the substrate $\mathrm{pH}$ of all intermediate $\mathrm{P}$ rates. All plants that received intermediate $P$ rates had recently mature 


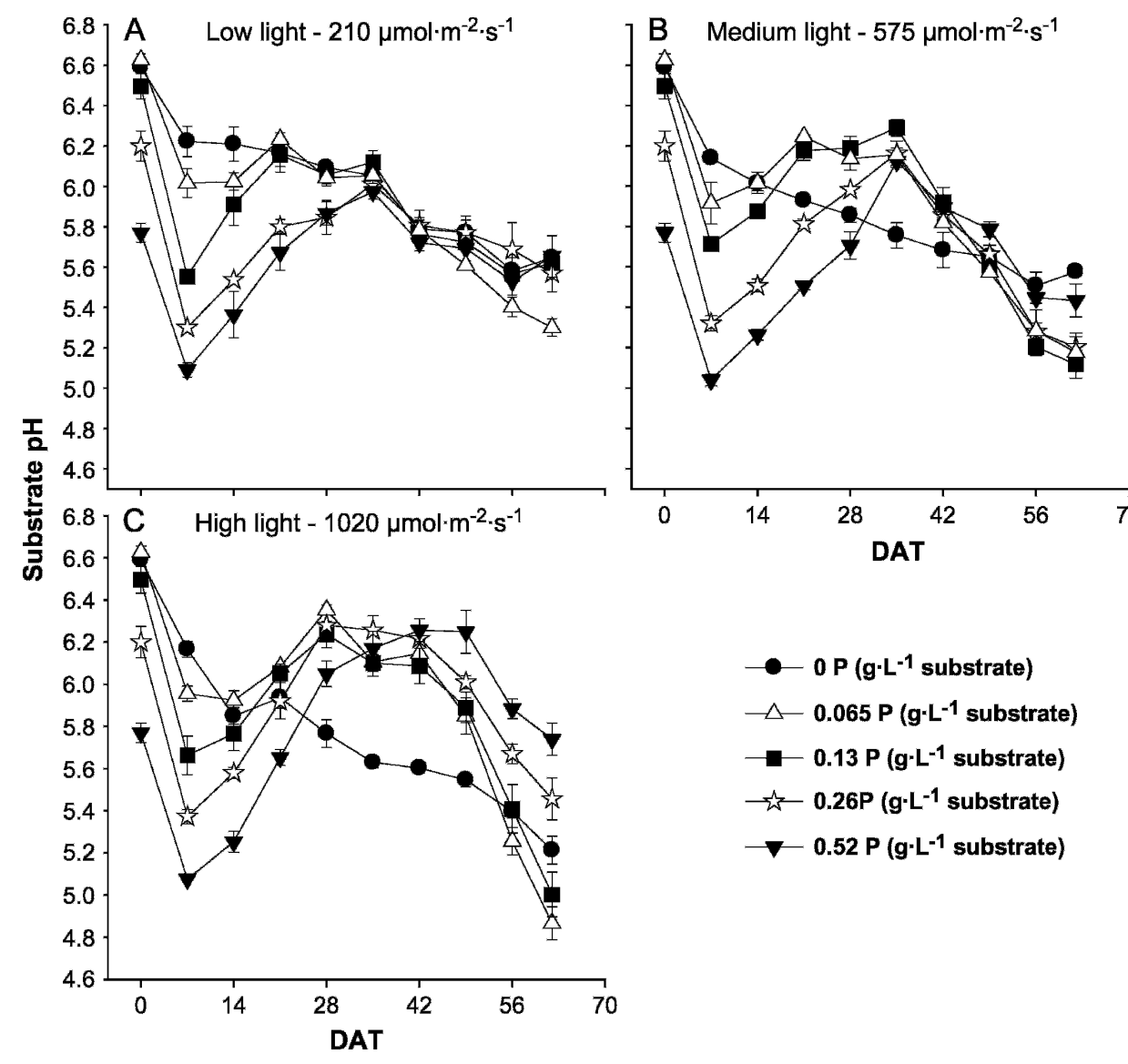

Fig. 2. Substrate $\mathrm{pH}$ of geraniums measured initially and every $7 \mathrm{~d}$ after transplanting (DAT) for each preplant treatment rate of $\mathrm{P}\left(0,0.065,0.13,0.26\right.$, and $0.52 \mathrm{~g} \cdot \mathrm{L}^{-1} \mathrm{P}$ in substrate $)$ at low $\left(210 \mu \mathrm{mol} \cdot \mathrm{m}^{-2} \cdot \mathrm{s}^{-1}\right)$, medium $(575$ $\left.\mu \mathrm{mol} \cdot \mathrm{m}^{-2} \cdot \mathrm{s}^{-1}\right)$, and high $\left(1020 \mu \mathrm{mol} \cdot \mathrm{m}^{-2} \cdot \mathrm{s}^{-1}\right)$ light intensities in Expt. 2. Error bars represent $\mathrm{SE}(\mathrm{n}=3)$.

Table 3. Dry weight percentage of $\mathrm{P}$ of recently mature leaves, shoot dry weight, and total shoot $\mathrm{P}$ determined from the average $\mathrm{P}$ concentration of recently mature and oldest leaves from geranium plants grown at low, medium, and high light $63 \mathrm{~d}$ after transplanting for Expt. 2.

\begin{tabular}{|c|c|c|c|c|c|}
\hline \multirow[b]{2}{*}{ Light treatment } & \multicolumn{5}{|c|}{ P rate $\left(\mathrm{g} \cdot \mathrm{L}^{-1}\right.$ substrate $)$} \\
\hline & 0 & 0.065 & 0.13 & 0.26 & 0.52 \\
\hline & & -----"- & $\mathrm{P}(\%)$ & ----- & $\overline{-------~}$ \\
\hline Low $\left(210 \mu \mathrm{mol} \cdot \mathrm{m}^{-2} \cdot \mathrm{s}^{-1}\right)$ & $0.08 \mathrm{a}^{\mathrm{z}}$ & $0.14 \mathrm{a}$ & $0.24 \mathrm{a}$ & $0.30 \mathrm{a}$ & $0.36 \mathrm{a}$ \\
\hline Medium $\left(575 \mu \mathrm{mol} \cdot \mathrm{m}^{-2} \cdot \mathrm{s}^{-1}\right)$ & $0.07 \mathrm{ab}$ & $0.08 \mathrm{~b}$ & $0.13 \mathrm{~b}$ & $0.17 \mathrm{~b}$ & $0.26 \mathrm{~b}$ \\
\hline High $\left(1020 \mu \mathrm{mol} \cdot \mathrm{m}^{-2} \cdot \mathrm{s}^{-1}\right)$ & $0.06 \mathrm{~b}$ & $0.07 \mathrm{c}$ & $0.09 \mathrm{~b}$ & $0.12 \mathrm{~b}$ & $0.20 \mathrm{c}$ \\
\hline Low $\left(210 \mu \mathrm{mol} \cdot \mathrm{m}^{-2} \cdot \mathrm{s}^{-1}\right)$ & $1.86 \mathrm{a}$ & $8.44 \mathrm{c}$ & $\begin{array}{l}\text { oot wt } \\
8.52 \mathrm{~b}\end{array}$ & $9.56 \mathrm{c}$ & $6.84 \mathrm{~b}$ \\
\hline Medium $\left(575 \mu \mathrm{mol} \cdot \mathrm{m}^{-2} \cdot \mathrm{s}^{-1}\right)$ & $1.53 \mathrm{a}$ & $14.96 \mathrm{~b}$ & $17.05 \mathrm{a}$ & $17.16 \mathrm{~b}$ & $18.40 \mathrm{a}$ \\
\hline High $\left(1020 \mu \mathrm{mol} \cdot \mathrm{m}^{-2} \cdot \mathrm{s}^{-1}\right)$ & $1.42 \mathrm{a}$ & $18.38 \mathrm{a}$ & $20.13 \mathrm{a}$ & $21.22 \mathrm{a}$ & $22.19 \mathrm{a}$ \\
\hline Low $\left(210 \mu \mathrm{mol} \cdot \mathrm{m}^{-2} \cdot \mathrm{s}^{-1}\right)$ & $0.12 \mathrm{a}$ & $1.18 \mathrm{a}$ & $\begin{array}{l}\text { I shoot } \mathrm{I} \\
1.97 \mathrm{ab}\end{array}$ & $2.85 \mathrm{a}$ & $2.05 \mathrm{~b}$ \\
\hline Medium $\left(575 \mu \mathrm{mol} \cdot \mathrm{m}^{-2} \cdot \mathrm{s}^{-1}\right)$ & $0.12 \mathrm{a}$ & $1.28 \mathrm{a}$ & $2.31 \mathrm{a}$ & $3.23 \mathrm{a}$ & $4.68 \mathrm{a}$ \\
\hline $\operatorname{High}\left(1020 \mu \mathrm{mol} \cdot \mathrm{m}^{-2} \cdot \mathrm{s}^{-1}\right)$ & $0.08 \mathrm{a}$ & $1.25 \mathrm{a}$ & $1.84 \mathrm{~b}$ & $2.76 \mathrm{a}$ & $4.46 \mathrm{a}$ \\
\hline
\end{tabular}

${ }^{\mathrm{z}}$ Mean separation (in columns) by Duncan's multiple range test at $P \leq 0.05$.

leaf percentage of $\mathrm{P}$ that was below the lower limit, which again indicates that $\mathrm{P}$ deficiency caused substrate acidification (Table 3 ). The effect of $\mathrm{P}$ rate on substrate $\mathrm{pH}$ at high light intensity again showed the same effect. At 63 DAT, when the $0 \mathrm{P}$ rate was excluded, substrate $\mathrm{pH}$ decreased from 5.74 to 4.87 as the $\mathrm{P}$ rate decreased. Additionally, tissue $\mathrm{P}$ was deficient in all treatments except at the $0.52 \mathrm{~g} \cdot \mathrm{L}^{-1} \mathrm{P}$ rate.
The light treatment $\times P$ rate interaction was significant for dry weight percentage of $\mathrm{P}$ of recently mature leaves $(P \leq 0.0152)$, shoot dry weight $(P \leq 0.0001)$, and total shoot P $(P \leq 0.0001)$ (Table 3$)$. Phosphorus concentration of recently mature leaves was significantly lower when plants were grown at high light compared with low light at all $\mathrm{P}$ rates and was lower than when plants were grown at medium light at the 0.065 and $0.52 \mathrm{~g} \cdot \mathrm{L}^{-1} \mathrm{P}$ rate. This suggests that high light intensity suppressed P uptake. The dry weight percentage of $\mathrm{P}$ of older leaves was unaffected by the light $\times P$ rate interaction and also decreased significantly as light intensity increased (Table 4), which again suggests that high light suppressed P uptake. Phosphorus content of older leaves also increased significantly with $P$ rate.

Shoot dry weight was unaffected by light treatment when plants received no added $\mathrm{P}$. At all other $\mathrm{P}$ rates, plants grown at low light weighed less than plants grown at medium and high light (Table 3). Plants grown at medium light weighed less than plants grown at high light at the 0.065 and $0.26 \mathrm{~g} \cdot \mathrm{L}^{-1} \mathrm{P}$ rate. In contrast, the total amount of $\mathrm{P}$ in shoots was generally not significantly affected by light treatment (Table 3 ). Thus, with the exception of low light at $0.52 \mathrm{~g} \cdot \mathrm{L}^{-1} \mathrm{P}$ and high light at 0.13 $\mathrm{g} \cdot \mathrm{L}^{-1} \mathrm{P}$, the rate of $\mathrm{P}$ uptake per gram dry weight plant decreased with increasing light intensity. Because increased $\mathrm{P}$ uptake did not correspond with increased growth, $P$ concentration may have been lower due to growth dilution when plants increased in size due to higher light intensity.

An additional factor that could have caused lower tissue percentage of $\mathrm{P}$ at higher light intensities was the higher number of irrigations required with increasing light intensity (Table 2). A higher number of irrigations could have caused increased leaching of preplant $\mathrm{P}$, making less $\mathrm{P}$ available for plant uptake. However, this does not appear to be true because the amount of $\mathrm{P}$ in pour-through substrate extracts averaged overall dates was unaffected by light treatment with the 0.065 and 0.52 $\mathrm{g} \cdot \mathrm{L}^{-1} \mathrm{P}$ treatments (Table 5). Also, at the $0.13 \mathrm{~g} \cdot \mathrm{L}^{-1} \mathrm{P}$ treatment, substrate extracts from plants grown at high and medium light intensity were statistically similar. At the $0.26 \mathrm{~g} \cdot \mathrm{L}^{-1} \mathrm{P}$ rate, pour-through extract $\mathrm{P}$ concentrations did decrease significantly with increasing light intensity. This trend is apparent 
Table 4. Main effects of light and $\mathrm{P}$ rate on dry weight percentage of $\mathrm{P}$ of oldest geranium leaves $63 \mathrm{~d}$ after transplanting from Expt. 2 . Plants from the $0 \mathrm{P}$ rate were insufficient for sampling.

\begin{tabular}{ll}
\hline & $\mathrm{P}(\%)$ \\
\hline Light treatment & \\
Low $\left(210 \mu \mathrm{mol} \cdot \mathrm{m}^{-2} \cdot \mathrm{s}^{-1}\right)$ & $0.24 \mathrm{a}^{\mathrm{z}}$ \\
Medium $\left(575 \mu \mathrm{mol} \cdot \mathrm{m}^{-2} \cdot \mathrm{s}^{-1}\right)$ & $0.18 \mathrm{~b}$ \\
High $\left(1020 \mu \mathrm{mol} \cdot \mathrm{m}^{-2} \cdot \mathrm{s}^{-1}\right)$ & $0.13 \mathrm{c}$ \\
P rate $\left(\mathrm{g} \cdot \mathrm{L}^{-1}\right.$ substrate $)$ & \\
0.065 & $0.098 \mathrm{~d}$ \\
0.13 & $0.16 \mathrm{c}$ \\
0.26 & $0.21 \mathrm{~b}$ \\
0.52 & $0.25 \mathrm{a}$ \\
\hline
\end{tabular}

${ }^{\mathrm{z}}$ Mean separation by Duncan's multiple range test at $P \leq 0.05$.

with other P treatments when statistics are not applied. The possibility that increased irrigations was responsible for lower tissue P seems likely; however, the effect of light on tissue $\mathrm{P}$ is more assertable than the effect on soil P. Phosphorus in pourthrough soil extracts was greatest at $14 \mathrm{DAT}$ for all $\mathrm{P}$ rates except zero, which did not change. Because higher light intensity indirectly increases irrigation frequency and potentially causes greater lime leaching, this could also be a contributing factor to SPD in a commercial setting.

ExPT. 3. The data from Expts. 1 and 2 indicate that $P$ deficiency causes substrate acidification by geranium and also indicates that high light intensity suppresses $\mathrm{P}$ uptake by roots. Expt. 3 verifies that high light intensity suppresses $\mathrm{P}$ uptake. There was no significant effect of light treatment on $\mathrm{pH}$ of hydroponic solution, shoot and whole plant dry weight, or root and shoot percentage of $\mathrm{P}$. Mean values at high $\left(1100 \mu \mathrm{mol} \cdot \mathrm{m}^{-2} \cdot \mathrm{s}^{-1}\right)$ and control $\left(550 \mu \mathrm{mol} \cdot \mathrm{m}^{-2} \cdot \mathrm{s}^{-1}\right)$ light levels were 5.68 and 5.34 for $\mathrm{pH}, 7.75$ and $6.61 \mathrm{~g}$ for shoot dry weight, 8.80 and $7.38 \mathrm{~g}$ for total dry weight, $1.48 \%$ and $1.48 \%$ for root $\mathrm{P}$, and $0.60 \%$ and $0.62 \%$ for shoot $\mathrm{P}$, respectively. When plants were grown at the control light intensity, root dry weight was significantly lower than plants grown at high light (Table 6). Cumulative $\mathrm{P}$ uptake per gram root and rate of $P$ uptake per gram root per day were significantly lower when plants were grown at the high light intensity compared with the control (Table 6). In two studies with tomato and one with boston fern, increasing light from 250 to 750,70 to 300 , and 50 to 150 Mmol $\cdot \mathrm{m}^{-2} \cdot \mathrm{s}^{-1}$, respectively, caused $\mathrm{P}$ uptake to increase (De Groot et al., 2001; Magalhaes and Wilcox, 1983; Nowak et al., 2002). A study by Ming et al. (1999) showed that P uptake by Dendrobium nobile Lindl. increased $74 \%$ when light intensity increased from 85 to $335 \mu \mathrm{mol} \cdot \mathrm{m}^{-2} \cdot \mathrm{s}^{-1}$ but decreased $29 \%$ when light intensity increased from 335 to $840 \mu \mathrm{mol} \cdot \mathrm{m}^{-2} \cdot \mathrm{s}^{-1}$.

${ }^{\mathrm{z}}$ Not detectable (ND).
These data indicate that increasing light intensity causes $\mathrm{P}$ uptake to increase, but there is a limit to this effect. Once this limit is reached, increasing light has a negative effect on $\mathrm{P}$ uptake. Expt. 3 verified this effect of supraoptimal light with geranium.

The main effects of DAT are also shown in Table 6 and as DAT increased, root dry weight increased and $\mathrm{P}$ remaining in the hydroponic tanks, cumulative $\mathrm{P}$ uptake per root weight, and $\mathrm{P}$ uptake per root weight per day decreased.

\section{Conclusion}

Clearly, high light intensity and $\mathrm{P}$ deficiency can be involved in SPD of geranium. It is not clear, however, if high light intensity contributes to substrate acidification if $\mathrm{P}$ is adequate. Further investigation of this question is warranted. In Expts. 1 and 2, when tissue $\mathrm{P}$ was below the range of $0.17 \%$ to $0.19 \%$, substrate $\mathrm{pH}$ dropped 0.6 to $1.0 \mathrm{pH}$ units within a 2-week period. Phosphorus deficiency also occurred more often under the highest light intensity of $1020 \mu \mathrm{mol} \cdot \mathrm{m}^{-2} \cdot \mathrm{s}^{-1}$. In Expt. 3, increasing light from 500 to $1100 \mu \mathrm{mol} \cdot \mathrm{m}^{-2} \cdot \mathrm{s}^{-1}$ decreased cumulative $\mathrm{P}$ and the rate of $\mathrm{P}$ uptake by $20 \%$, indicating that excessive light has the potential to cause $\mathrm{P}$ deficiency in geranium. The daily light integral during the spring for most of the continental United States ranges from 25 to 50 $\mathrm{mol} \cdot \mathrm{m}^{-2} \cdot \mathrm{d}^{-1}$ (Fisher and Runkle, 2004). Eight hours per day of the high-light treatments in this study provided a daily light integral of $29.4 \mathrm{~mol} \cdot \mathrm{m}^{-2} \cdot \mathrm{d}^{-1}$ (Expts. 1 and 2) and 31.7 $\mathrm{mol} \cdot \mathrm{m}^{-2} \cdot \mathrm{d}^{-1}$ (Expt. 3), which were below some of the levels

Table 5. Main effects of light and days after transplanting (DAT) on P concentration in pourthrough substrate extracts from geranium in Expt. 2.

\begin{tabular}{lccccr}
\hline & \multicolumn{5}{c}{ P rate $\left(\mathrm{g} \cdot \mathrm{L}^{-1}\right.$ substrate $)$} \\
\cline { 2 - 6 } & 0 & 0.065 & 0.13 & 0.26 & 0.52 \\
\hline Light treatment & & & Soil $\mathrm{P}\left(\mathrm{mg} \cdot \mathrm{L}^{-1}\right)$ \\
Low $\left(210 \mu \mathrm{mol} \cdot \mathrm{m}^{-2} \cdot \mathrm{s}^{-1}\right)$ & $\mathrm{ND}^{\mathrm{z}}$ & $2.65 \mathrm{a}^{\mathrm{y}}$ & $9.37 \mathrm{a}$ & $25.7 \mathrm{a}$ & $41.8 \mathrm{a}$ \\
Medium $\left(575 \mu \mathrm{mol} \cdot \mathrm{m}^{-2} \cdot \mathrm{s}^{-1}\right)$ & $\mathrm{ND}$ & $2.26 \mathrm{a}$ & $4.13 \mathrm{~b}$ & $16.8 \mathrm{~b}$ & $40.0 \mathrm{a}$ \\
High $\left(1020 \mu \mathrm{mol} \cdot \mathrm{m}^{-2} \cdot \mathrm{s}^{-1}\right)$ & $\mathrm{ND}$ & $1.09 \mathrm{a}$ & $3.94 \mathrm{~b}$ & $8.33 \mathrm{c}$ & $28.9 \mathrm{a}$ \\
DAT & & & & & \\
14 & $\mathrm{ND}$ & $6.92 \mathrm{a}$ & $19.1 \mathrm{a}$ & $54.0 \mathrm{a}$ & $115.4 \mathrm{a}$ \\
28 & $\mathrm{ND}$ & $0.93 \mathrm{~b}$ & $3.21 \mathrm{~b}$ & $10.9 \mathrm{~b}$ & $25.2 \mathrm{~b}$ \\
42 & $\mathrm{ND}$ & $0.13 \mathrm{~b}$ & $0.75 \mathrm{~b}$ & $2.19 \mathrm{c}$ & $5.45 \mathrm{c}$ \\
56 & $\mathrm{ND}$ & $0.02 \mathrm{~b}$ & $0.18 \mathrm{~b}$ & $0.58 \mathrm{c}$ & $1.54 \mathrm{c}$ \\
\hline
\end{tabular}

'Mean separation (in columns) by Duncan's multiple range test at $P \leq 0.05$.

Table 6. Main effect of light treatment and days after transplanting (DAT) on geranium root dry weight, the remaining P of $124 \mathrm{mg}$ in $4 \mathrm{~L}$ of hydroponic solution, cumulative $\mathrm{P}$ uptake per gram dry weight of root, and P uptake per gram dry weight of root per day in Expt. 3.

\begin{tabular}{|c|c|c|c|c|}
\hline & $\begin{array}{l}\text { Root dry } \\
\text { wt (g) }\end{array}$ & $\begin{array}{l}\text { P remaining } \\
(\mathrm{mg})\end{array}$ & $\begin{array}{c}\text { P uptake } \\
\text { per unit dry } \\
\text { root wt }\left(\mathrm{mg} \cdot \mathrm{g}^{-1}\right)\end{array}$ & $\begin{array}{c}\text { P uptake } \\
\text { per unit root } \\
\text { dry wt }\left(\mathrm{mg} \cdot \mathrm{g}^{-1} \cdot \mathrm{d}^{-1}\right)\end{array}$ \\
\hline \multicolumn{5}{|l|}{ Light treatment } \\
\hline Control $\left(500 \mu \mathrm{mol} \cdot \mathrm{m}^{-2} \cdot \mathrm{s}^{-1}\right)$ & 0.767 & 62.8 & 86.3 & 6.96 \\
\hline $\operatorname{High}\left(1100 \mu \mathrm{mol} \cdot \mathrm{m}^{-2} \cdot \mathrm{s}^{-1}\right)$ & 1.05 & 53.6 & 69.6 & 5.55 \\
\hline Significance & * & NS & ** & ** \\
\hline \multicolumn{5}{|l|}{ DAT } \\
\hline 11 & 0.538 & 78.7 & 87.3 & 7.94 \\
\hline 15 & 1.28 & 37.7 & 68.5 & 4.57 \\
\hline Significance & *** & ** & ** & *** \\
\hline
\end{tabular}


experienced during spring geranium production. The recommended light intensity for the production of zonal geraniums ranges from 700 to $800 \mu \mathrm{mol} \cdot \mathrm{m}^{-2} \cdot \mathrm{s}^{-1}$ (Fischer USA, 2007; Hamrick, 2003). These intensities are lower than the high light intensities used in this study $\left(1030\right.$ and $\left.1100 \mu \mathrm{mol} \cdot \mathrm{m}^{-2} \cdot \mathrm{s}^{-1}\right)$ and it is highly likely during normal geranium production that light will exceed these recommendations, especially in the late spring and in the southern regions of the United States. To help prevent SPD, geranium growers should avoid $\mathrm{P}$ deficiency, which was shown in this study to cause substrate acidification. If possible, growers should also avoid extended periods of highintensity light, which can suppress $P$ uptake and cause substrate acidification. Additionally, because other factors are likely involved with SPD, substrate $\mathrm{pH}$ must be regularly monitored to identify possible oncoming $\mathrm{pH}$ problems that can be corrected by application of flowable limestone.

\section{Literature Cited}

Anita, M.R., S. Lakshmi, S.J. Pillai, and P. Saraswathi. 2003. Nutrient uptake by guinea grass (Panicum maximum J.) under varying light intensities. Forage Res. 29:107-109.

De Groot, C.C., L.F.M. Marcelis, R. Van Den Boogaard, and H. Lambers. 2001. Growth and dry-mass partitioning in tomato as affected by phosphorus nutrition and light. Plant Cell Environ. 24:1309-1317.

Fisher, P. and E. Runkle. 2004. Lighting up profits. Understanding greenhouse lighting. Meister Media, Willoughby, $\mathrm{OH}$.

Fischer, U.S.A. 2007. Producing high quality geraniums, p. 57-74. In: Fischer cultural guide 2007-2008. Fischer USA, Boulder, CO.

Hamrick, D. 2003. Ball redbook. Volume 2: Crop production. 17th ed. Ball Publishing, Batavia, IL.

Hinsinger, P. 2001. Bioavailability of soil inorganic P in the rhizosphere as affected by root-induced chemical changes: A review. Plant Soil 237:173-195.
Khasawneh, F.E., E.C. Sample, and E.J. Kamprath. 1978. The role of phosphorus in agriculture. Amer. Soc. Agron., Crop Sci. Soc. Amer., Soil Sci. Soc. Amer., Madison, WI.

Krug, B.A., B.E. Whipker, B. Cleavland, and I. McCall. 2006. Taking the "art" out of interpreting tissue analysis for geranium. Proc. Southern Nursery Assn. Res. Conf. 15:635-639.

Magalhaes, J.R. and G.E. Wilcox. 1983. Tomato growth and mineral composition as influenced by nitrogen form and light intensity. J. Plant Nutr. 6:847-862.

Marschner, H. 1995. Mineral nutrition of higher plants. Academic Press. New York.

Ming, Z., B. Zhilong, C. Shijiang, W. Zhaoliang, Z. Yujin, Z. Liquan, and L. Quansen. 1999. Effects of temperature and light intensity on $P$ uptake in dendrobe (Dendrobium nobile Lindl.). J. Southwest Agr. Univ. 21:220-222.

Murphy, J. and J.P. Riley. 1962. A modified single solution method for the determination of phosphate in natural waters. Anal. Chem. Acta 27:31-36.

Naegle, E.R., J.W. Burton, T.E. Carter, and T.W. Rufty. 2005. Influence of seed nitrogen content of seedling growth and recovery form nitrogen stress. Plant Soil 271:329-340.

Nowak, J., S. Sroka, and B. Matysiak. 2002. Effects of light level, $\mathrm{CO}_{2}$ enrichment, and concentration of nutrient solution on growth, leaf nutrient content and chlorophyll fluorescence of boston fern microcuttings. J. Plant Nutr. 25:2161-2172.

Schjorring, J.K. 1986. Nitrate and ammonium absorption by plants growing at a sufficient or insufficient level of phosphorus in nutrient solution. Plant Soil 91:313-318.

Taylor, M.D., P.V. Nelson, and J.M. Frantz. 2008. Substrate acidification by geranium: Temperature effects. J. Amer. Soc. Hort. Sci. 133:508-514.

White, J.W. 1993. Geraniums IV. The grower's manual. Ball Publishing. Batavia, IL.

Wright, R.D. 1986. The pour-through nutrient extraction procedure. HortScience 21:227-229. 